\title{
A responsabilidade do professor na seleção das técnicas didáticas
}

\section{RESUMO}

Reconhecendo o valor da seleção criteriosa das técnicas didáticas no processo ensino-aprendizagem, o autor chama a atenção do docente para sua responsabilidade nessa seleção.

São freqüentes os depoimentos dos professores acerca das dificuldades dos alunos quanto à leitura, à pesquisa bibliográfica, à expressão oral, ou escrita, ou ao raciocínio.

De tão repetidos e enfáticos, tais depoimentos parecem indiscutíveis. Todavia, sondar as razões daquelas dificuldades apresenta-se como tarefa interessante, séria e oportuna.

Há razões dependentes do ambiente, do professor e do estudante, que não se excluem, mas interagem, contribuindo para delinear o quadro - dito tão desolador - da educação escolar.

Sem negligenciar as outras variáveis, vale sublinhar a importância da ação do profissional diretamente encarregado do processo ensinoaprendizagem: o professor.

Quando se pergunta quem é esta figura poderosa, temida, respeitada, amada, a resposta é pronta e familiar: o professor é alguém que ensina. Ou mais: é alguém com poder, socialmente instituído, para influenciar aqueles que estão sob a tutela do seu saber, de suas crenças, de sua forma de ser. Alguém capacitado a ensinar conceitos, valores e regras.

Como profissional do ensino, o professor, em geral, conhece conceituações de aprendizagem, podendo, por exemplo, repetir com Schmitz, que "a aprendizagem representa uma modificação mais ou menos estável nos modos de perceber, ser, pensar e agir das pessoas" ${ }^{3}$. Sabe ele, também, que a aprendizagem é pessoal, ativa, intencional e automotivada. Possuidor desses conhecimentos, e os aceitando, o professor pode repensar o significado de sua tarefa: criar condições que permitam a aprendizagem.

Comprometer-se com a aprendizagem, minimizando a primazia do ato de ensinar, é assumir a humildade de reconhecer que só há ensino se alguém aprende o que se ensina.

Aceitar esta constatação é redimensionar a sua responsabilidade e redefinir o seu papel no processo ensino-aprendizagem. É saber que ser professor é ser pessoa, profissionalmente equipada, que interage com outra(s), contribuindo para seu destino existencial.

Sabe-se que esse profissional não nasce feito nem, a rigor, se improvisa. Forma-se. Tanto mais será um profissional competente quanto mais, ao lado do domínio de uma área específica do conhecimento, dispuser de conhecimento sobre a pessoa humana - o aluno - e sobre as condições que afetam a sua aprendizagem.

Assim situado, o professor poderá aquilatar a responsabilidade de cada um nos acertos e erros da educação. Com serenidade, saberá que pode contribuir para modificar o quadro. Ainda que modestamente.

Uma das formas iniciais de o professor revelar seu compromisso com a melhoria da qualidade da educação é selecionar com critério as técnicas didáticas que favoreçam a real aprendizagem.

Se a escolha dos objetivos, do conteúdo e dos métodos de avaliar não Ihe tem sido atribuída, cabe-lhe a seleção das técnicas didáticas, de inestimável importância no trabalho pedagógico que cumpre ao professor desempenhar. "Poucos são os professores que se dão conta da relação direta que existe entre a maneira de ensinar e os

* Membro da Equipe Pedagógica da ABEM. 
resultados que esperam alcançar" ${ }^{1}$.

Em geral, os professores esperam que seus alunos alcancem o domínio de conteúdos cognitivos. Entretanto, esta é apenas parte da tarefa da escola, que tem compromisso, também, com a formação de atitudes do aluno, e responsabilidades para com a sociedade.

Se não se concentram esforços para estabelecer os objetivos de uma escola, de um departamento, de uma disciplina, pode ocorrer que ensino e aprendizagem se processem de forma imprecisa, sem metodologia. Esta só se define com clareza se baseada em objetivos previamente determinados.

Pode-se desejar que o aluno aprenda, por exemplo, a ler, ouvir, auscultar, discutir, diagnosticar, prevenir, tratar. Por serem ações diferentes, ainda que complementares, caberá ao professor procurar meios para que cada uma delas se cumpra.

Pretendendo que os alunos aprendam informações, o professor pode oferecer-lhes como meio de aprendizagem, por exemplo, aulas expositivas, ou pesquisas em biblioteca. No dizer de Bridge, "infelizmente, em muitas escolas de medicina, a aprendizagem se baseia tanto em aulas magistrais, que não sobra muito tempo para que se obtenham informações por outros meios"1.

Desejando que os alunos relacionem, sintetizem, julguem, o professor pode eleger como procedimentos didáticos, discussões em grupo, seminários, sessões clínicas. Estas técnicas favorecem a aprendizagem ativa, e o bom êxito delas depende, em grande parte, do professor. A ele cabe sugerir um tema apropriado ao interesse e às necessidades dos alunos, bem como criar um clima que propicie a livre expressão de idéias e a seriedade na busca de soluções.

Outra forma de proporcionar a aprendizagem ativa é o trabalho em laboratório que pode servir a muitos objetivos, dentre os quais, segundo Miller, o mais marcante é "a aquisição de sólida compreensão de fatos ouvidos em preleções, lidos em livros, ou periódicos, observados em demonstrações, ou discutidos nos debates. $\mathrm{O}$ aluno tem condições de obtê-la através de experiência direta cujo resultado depende de iniciativa e habilidades suas, mais a responsabilidade pessoal inerente à situação, e o desafio que represen$\mathrm{ta}^{\prime \prime 2}$.

O laboratório permite também adquirir aptidões específicas na manipulação de equipamento, de conceitos matemáticos, em observação, análise dos dados e síntese de resultados.
Vale, aqui, relembrar depoimentos de muitos professores a respeito do desempenho de seus alunos nas chamadas "aula teórica" e "aula prática". Em suas observações, é nas "práticas" que os estudantes demonstram maior interesse, responsabilidade, vivacidade, efetivo empenho em trabalhar.

Essa opinião é reforçada por Bridge, ao descrever duas situações: na primeira, os alunos decoravam, em murmúrio, ou em voz alta, "fórmulas bioquímicas e o diagnóstico diferencial da hérnia umbilical" para sair-se bem nos exames; na segunda, em laboratórios e enfermarias, estudavam "a natureza diretamente, através da experimentação, ou de observação, e cuidados a pessoas doentes" ${ }^{\prime 1}$. Na primeira, mostravam-se ansiosos e temerosos; na segunda, interessados e autoconfiantes.

Tais fatos levam a pensar na responsabilidade do professor em procurar fazer a "teoria" tão atraente quanto a "prática". Mais que isso, porém, levam à urgente obrigação de não dissociar a teoria da prática.

Aprende-se teoria tanto em aulas expositivas, quanto em discussões em grupo, ou em trabaIhos de laboratórios. Aprende-se prática não só em laboratório, ou à beira do leito do doente, mas, também, em visitas e discussões, entendendo-se por prática tanto atividades mentais, quanto psicomotoras. Teoria e prática não se excluem, antes se completam: são aspectos de um todo, o conhecimento.

E, pois, necessário, que o professor selecione e reorganize experiências de aprendizagem que possibilitem reduzir o hiato entre o discurso e a ação, entre o que se teoriza e o que se pratica.

Informação, compreensão, destreza, são objetivos que devem convergir para o objetivo maior de qualquer escola: a formação de atitudes.

Os professores, por vezes, preocupam-se mais em transmitir conteúdos cognitivos e facilitar o domínio de técnicas que em modificar e criar atitudes.

Essa dificuldade talvez advenha do fato de que atitudes não podem ser "ensinadas" diretamente e de forma sistematizada. Mas o professor, mesmo sem se dar conta, influencia o estudante com sua presença, sua maneira de tratá-lo, a atenção que lhe dispensa, a forma como relata um conteúdo cognitiv Assim é que o professor pode oferecer ao aluno condições para aceitar passivamente fatos e idéias, ou condições para observar, raciocinar, discutir, indagar.

Convém enfatizar que a técnica, por si, não 
garante a qualidade da educação. Técnica é meio e, como tal, está subordinada a fins.

Que o professor saiba para que fins empenha seu esforço e, a partir daí, selecione as técnicas mais adequadas para atingi-los, são requisitos fundamentais para criar condições de real aprendizagem. Mas que tudo, porém, convém conhecer seu aluno.

Segundo Miller, "se o professor, use o método que usar, não conseguir provocar o aluno, ou se apenas o fizer por meio de exames periódicos, tempo e esforço de ambas as partes não estarão sendo bem aproveitados, é quase certo... É imprescindível que os professores, com vistas a aprendizagem mais proveitosa, saibam alguma coisa a respeito de seus alunos como indivíduos seus antecedentes, hábitos de trabalho e de pensamento - e dêem ensejo a que cada um encontre e use o ambiente que for mais propício à sua produtividade, porque nem classes grandes, nem horário de aulas limitado etc., mudam o fato básico de que os estudantes são indivíduos e como tal devem aprender"2.

\section{SUMMARY}

Acknowledging the value of the judicious selection of the didatic technics in the teaching and learning process the author calls the attention of the teacher's responsability for that selection.

\section{REFERẼNCIAS BIBLIOGRĀFICAS}

1. BRIDGE, E. M. - Pedagogia médica. NY, Organización Panamericana de la Salud. OMS, 1965.

2. MILLER, G. E. - Ensino e aprendizagem nas escolas médicas. São Paulo, Companhia Editora Nacional, 1967.

3. SCHMITZ, E. F. - Didática moderna-fundamentos. Rio, Livros Técnicos e Científicos, 1980.

\section{Endereço do autor:}

Associação Brasileira de Educação Médica Rua Leopoldo Bulhões, 1480 - 30 andar 21041 - Manguinhos

Rio de Janeiro - RJ 